\title{
The Connection between Indonesian Language Learning and Environmental Materials
}

\author{
Ghina Kamilah Siregar 18016157 \\ Universitas Negeri Padang-FBS \\ ghkamilah@gmail.com
}

The environment has a very important role for life. To be able to protect our environment requires understanding and knowledge of the environment. According to Ramadhan et.al (2019) in Indonesia environmental education is not a compulsory subject in schools. Therefore, environmental education can be integrated into other subjects, one of which is language learning. Sukma, Ramadhan, and Indriyani (2020) said that the important role of environmental education is to develop individuals who have scientific knowledge of environmental issues and high environmental concern and have the potential to help future generations manage life and build a prosperous future. Angin, Ramadhan, and Agustina (2015) said that using environmental materials made students more sensitive to their environment because they could present their observations.

Ramadhan et.al (2019) said that teachers play an important role in conveying this knowledge to students, because students are the next generation who are tasked with protecting the environment. Environmental education can be integrated into language learning lessons. This integration can be done by using the theme of the environment in text learning. It is through the text that students can learn the language and gain environmental knowledge through the content of the text they read.

According to Sukma (2016) Language learning is an interesting learning. Sukma (2005) states that language learning requires a teacher to be able to develop various techniques and variations in techniques that can increase student interest in learning. Teachers must know what their students need, not just meaningless learning. Ramadan et.al (2019) said that the use of environmental themes in text learning can trigger students 'interest in learning languages and can implicitly increase students' knowledge of the environment. Wasillah, Ramadhan, and Noveria (2016) said that language 
learning can also improve language skills, broaden horizons, and encourage students to have communicative literary skills.

Environmental material in Indonesian language learning is very important and interrelated material, because by having a good understanding of environmental material, especially in Indonesian language learning, a student will have sensitivity and concern for their environment, especially the classroom environment in learning Indonesian. In learning Indonesian in schools, teachers must explain environmental material in Indonesian language learning in schools to preserve the environment. Sukma (2019) states that teachers should provide material that is suitable for students' conditions, age, interests, habits, and life environment.

Environmental based learning aims to make students participate in protecting the environment. Not seeing the environment as something that can be exploited for personal gain, but as a valuable asset that deserves to be protected for human survival. Therefore, it is important to develop knowledge about the environment, environmental awareness and changes in behavior towards the environment. Environmental education can help students rethink the relationship between humans and the environment, understand the environment, be aware of environmental problems and consider environmental problems related to life (Ramadhan et.al, 2019).

Based on the problems described above, the authors conducted research on the importance of environmental materials in Indonesian language learning. The research was conducted by making 10 statements in the form of a google form questionnaire with the title "The Linkage of Indonesian Language Learning with Environmental Materials". The questionnaire respondents consisted of 43 people, namely 2 teachers, 39 students and 2 students. The teachers came from MTsN 1 Padang Pariaman and SMP Negeri 6 Panyabungan. The students came from the University of North Sumatra in semester V, Padang State University in semester V and VII, PKN STAN semester III, Medan State University in semester V, Bandung Institute of Technology in semester V, University of Indonesia in semester V, Bogor Agricultural Institute in semester V, STEI STEBI semester III, Syiah Kuala University State Islamic University of North Sumatra, Andalas University semester V, Poltekpar Medan semester V, Tourism Polytechnic semester V, Muhammadiyah University of North Sumatra semester V. Students come 
from SMAN 2 Plus Panyabungan class XII and MTsN 2 Madina class IX. Respondents are also required to include gender. From the total number of respondents who filled out the questionnaire, it turned out that women were more dominant than men, with the percentage of women (79.07\%) and men (20.93\%).

The results obtained from this study are as follows. The first statement is that environmental material is very important in learning Indonesian, getting 58.14\% agree, $41.86 \%$ strongly agree, $0 \%$ disagree, and $0 \%$ disagree. The second statement is that the environmental material makes it easier for students to understand Indonesian language learning to get $53.49 \%$ agree on results, $41.86 \%$ strongly agree, $4.65 \%$ disagree and disagree with $0 \%$. The third statement is that environmental material is feasible to be one of the Indonesian language learning media, getting results agree $60.5 \%$, strongly agree $39.5 \%$, disagree $0 \%$, and disagree $0 \%$. The fourth statement is that environmental material can reduce boredom and boredom of students in learning to get results strongly agree $55.8 \%$, agree $37.2 \%$, disagree $4.65 \%$ and disagree $2.33 \%$. The fifth statement is that environmental material is a conditional factor that creates a conducive learning atmosphere that can develop activities and creativity in learning optimally, get $58.1 \%$ agree, strongly agree $39.5 \%$, disagree $2.33 \%$ and disagree $0 \%$. The sixth statement is one of the factors that influence student learning outcomes is an environment that gets results strongly agree $48.8 \%, 48.8 \%$ agree, disagree $2.33 \%$ and disagree $0 \%$. The seventh statement, namely the use of the environment is one of the learning media that is good to be applied in the learning process which gets the results strongly agree $55.8 \%$, agree $44.2 \%$, disagree $0 \%$, and disagree $0 \%$. The eighth statement, namely environmental material can be linked to explanatory text which contains an explanation of an event or phenomenon related to nature, social, scientific, and cultural, getting results strongly agree $51.2 \%$, agree $46.5 \%$, disagree $2.33 \%$, and $0 \%$ disagree. The ninth statement, namely the environmental approach is a learning approach that seeks to increase student involvement through the use of the environment as a source of division who get $65.1 \%$ agree, $32.6 \%$ strongly agree, $2.33 \%$ disagree and $0 \%$ disagree. The tenth statement, namely Indonesian language learning and environmental material is closely related and inseparable, which get $76.7 \%$ agree, $20.9 \%$ strongly agree, $0 \%$ disagree, and $0 \%$ disagree. 
Based on the results of studies and research conducted by the author, it can be concluded that environmental material has an important role and is also related to Indonesian language learning. Environmental insight education can be integrated into Indonesian subjects and subjects to provide comprehensive knowledge and skills in protecting the environment. Environmental materials can also make it easier for educators to teach learning materials, especially in Indonesian language learning. Based on research conducted by the writer, the sound obtained shows that environmental material has a close relationship with Indonesian language learning. 


\section{Attachment Summary of Questionnaire Results}

“The Connection between Indonesian Language Learning and Environmental

Materials"

\begin{tabular}{|l|c|c|c|c|}
\hline \multicolumn{1}{|c|}{ Statement } & $\begin{array}{c}\text { Strongly } \\
\text { agree }\end{array}$ & Agree & $\begin{array}{c}\text { Less } \\
\text { agree }\end{array}$ & Disagree \\
\hline $\begin{array}{l}\text { Environmental materials are very } \\
\text { important in learning Indonesian }\end{array}$ & $41 \%$ & $\mathbf{5 8 \%}$ & - & - \\
\hline $\begin{array}{l}\text { Environmental materials make it } \\
\text { easier for students to understand } \\
\text { Indonesian language learning }\end{array}$ & $\mathbf{5 3 , 5 \%}$ & $41,9 \%$ & $4,65 \%$ & - \\
\hline $\begin{array}{l}\text { Environmental material deserves to } \\
\text { be one of the Indonesian language } \\
\text { learning media }\end{array}$ & $39,5 \%$ & $\mathbf{6 0 , 5 \%}$ & - & - \\
\hline $\begin{array}{l}\text { Environmental materials can } \\
\text { reduce boredom and boredom of } \\
\text { students in learning. }\end{array}$ & $\mathbf{5 5 , 8 \%}$ & $37,2 \%$ & $4,65 \%$ & $2,33 \%$ \\
\hline $\begin{array}{l}\text { Environmental material is a } \\
\text { conditional factor that creates a } \\
\text { conducive learning atmosphere that } \\
\text { can develop optimal learning } \\
\text { activities and creativity }\end{array}$ & $39,5 \%$ & $\mathbf{5 8 , 1 \%}$ & $2,33 \%$ & - \\
\hline $\begin{array}{l}\text { One of the factors that influence } \\
\text { student learning outcomes is the } \\
\text { environment }\end{array}$ & $\mathbf{4 8 , 8 \%}$ & $48,8 \%$ & $2,33 \%$ & - \\
\hline $\begin{array}{l}\text { Utilization of the environment is } \\
\text { one of the good learning media to } \\
\text { be applied in the learning process }\end{array}$ & $\mathbf{5 5 , 8 \%}$ & $44,2 \%$ & - & - \\
\hline $\begin{array}{l}\text { Environmental material can be } \\
\text { associated with explanatory text } \\
\text { which contains an explanation of } \\
\text { an event or phenomenon related to } \\
\text { natural, social, scientific, and } \\
\text { cultural. }\end{array}$ & $\mathbf{5 1 , 2 \%}$ & $46,5 \%$ & $2,33 \%$ & - \\
\hline $\begin{array}{l}\text { The environmental approach is a } \\
\text { learning approach that seeks to } \\
\text { increase student involvement } \\
\text { through the utilization of the } \\
\text { environment as a learning resource }\end{array}$ & $32,6 \%$ & $\mathbf{6 5 , 1 \%}$ & - & \\
\hline $\begin{array}{l}\text { Indonesian language learning and } \\
\text { environmental materials are closely } \\
\text { related and cannot be separated }\end{array}$ & $\mathbf{2 0 . 9 \%}$ & $\mathbf{7 6 , 7 \%}$ & $2,33 \%$ & - \\
\hline
\end{tabular}




\section{References}

Ramadhan, S., Sukma, E., \&Indriyani, V. (2019). Environmental education and disaster mitigation through language learning

Ramadhan, S., Sukma, E., \& Indriyani, V. (2019). Environmental education and disaster mitigation through language learning. IOP Conference Series: Earth and Environmental Science, 314, pp. 1-9.

Ramadhan, S., Zaim M., Atmazaki., \& Indriyani, V.(2019) Literasi Baca Tulis dan Inovasi Kurikulum Bahasa: Jurnal Kembara. Vol 5 No 1.

Ramadhan, S., Sukma, E., \& Indriyani, V. (2019). Persepsi Guru Terhadap Penggunaan Bahan Ajar Bahasa Indonesia Dengan Perangkat Seluler dan Aplikasi Edmodo: Seminar Internasional Riksa Bahasa XIII.

Wasilah, Tri, R., Syahrul, Noveria, Ena. (2016). Pengaruh Model Pembelajaran Kooperatif Tipe Think Pair Share terhadap Keterampilan Menulis Naskah Drama Satu Babak Siswa Kelas VIII SMP Negeri 30 Padang. Jurnal Pendidikan Bahasa dan Sastra Indonesia. 5(1); 810.

Angin, Toras Barita Bayo, Ramadhan, Syahrul, Agustina. (2015). Berbasis Pendekatan Kontekstual Pada Menulis Iklan Di Kelas VIII SMP 2 Padangsidimpuan Sumatera Utara. Jurnal Bahasa, Sastra, dan Pembelajaran. 3(1); 27-31.

Sukma, E. (2005). Penerapan Pendekatan Komunikatif dalam Pembelajaran Struktur Bahasa Indonesia di Sekolah Dasar. Diksi. Vol 2 No.1

Sukma, E. (2019). Problem in oral language teaching in primary school. Seventh international conference on languages and arts(ICLA 2018). Atlantis press.

Sukma, E, Ramadhan, S, Indriyani, V. 2020. Integration Of Environmental Education In Elementary Schools. Journal of Physics: Conference Series.1481(1): 1-2.

Sukma dan Bacthiar (2016). Kompetensi kognitif pembelajaran apresiasi sastra di sekolah dasar. Jurnal Gramatika. 2(1). 